\begin{tabular}{|l|l|l|}
\hline \multicolumn{2}{|c|}{ PublisherInfo } \\
\hline \hline PublisherName & $:$ & BioMed Central \\
\hline \hline PublisherLocation & $:$ & London \\
\hline \hline PublisherImprintName & $:$ & BioMed Central \\
\hline \hline
\end{tabular}

\title{
Do cellular phones really interfere with monitoring?
}

\begin{tabular}{|l|l|l||}
\hline \multicolumn{2}{|c||}{ ArticleInfo } \\
\hline \hline ArticleID & $:$ & 4302 \\
\hline \hline ArticleDOI & $:$ & $10.1186 /$ ccf-2001-73254 \\
\hline \hline ArticleCitationID & $:$ & 73254 \\
\hline \hline ArticleSequenceNumber & $:$ & 13 \\
\hline \hline ArticleCategory & $:$ & Paper Report \\
\hline \hline ArticleFirstPage & $:$ & 1 \\
\hline \hline ArticleLastPage & $:$ & 3 \\
\hline \hline & & RegistrationDate : 2001-12-4 \\
ArticleHistory & $:$ & Received \\
\hline ArticleCopyright & $:$ & Biomed Central Ltd2001-4-2 \\
\hline \hline ArticleGrants & $:$ & \\
\hline \hline ArticleContext & $:$ & 1305455 \\
\hline \hline
\end{tabular}


Aff1 Southampton General Hospital, UK

\section{Keywords}

Cardiac monitoring, interference, mobile phones

\section{Context}

Hospitals frequently ban the use of mobile telephones around theatres and ICUs because it is perceived that they interfere with wireless devices and patient monitoring systems. These policies are not, however, evidence based. This study tested several different mobile telephones with a range of cardiac monitors, defibrillators, ventilators, and intra-aortic balloon pumps.

\section{Significant findings}

Interference on the ECG occurred in 41\% (7 of 17) of monitors and in $54.7 \%$ of the 526 tests performed. Interference thought to be clinically significant (ie would have made interpretation difficult) occurred in $7.4 \%$. Baseline movement or noise on the ECG was the most common occurrence. One ventilator (Veolar Hamilton) could be switched off when a mobile phone was held against the communications port. One phone caused baseline interference 84 inches from a monitor. Only when a phone was used in close proximity to a monitor did limited interference occur. This was not thought to be clinically significant.

\section{Comments}

It is interesting to finally see some work that rationalises the ban on mobile phones. The conclusion from the authors is that the work is not conclusive as not all makes were tested, However it seems highly unlikely that clinically relevant problems will occur if common sense prevails. 


\section{Methods}

Monitoring devices were approached from various angles by switched on mobile phones. These tests were repeated with phone ringing.

\section{Additional information}

\section{References}

1. Tri JL, Hayes DL, Smith TT, Severson RP: Cellular phone interference with external cardiopulmonary monitoring devices. Mayo Clinic Proc. 2001, 76: 11-15. 